\title{
Barriers to implement green supply chain management in automobile industry using interpretive structural modeling technique-An Indian perspective
}

\author{
Sunil Luthra ${ }^{1}$, Vinod Kumar ${ }^{1}$, Sanjay Kumar ${ }^{2}$, Abid Haleem ${ }^{3}$ \\ ${ }^{1}$ Thapar University (INDIA); ${ }^{2}$ C.B.S Group of Institutions (INDLA); ${ }^{3}$ Jamia Millia Islamia \\ (INDLA) \\ sunilluthra1977@gmail.com; vsingla@,thapar.edu; skbhardwaj19711971@gmail.com; \\ baleem.abid@gmail.com
}

Received September 2010

Accepted March 2011

\section{Abstract:}

Purpose: Green Supply Chain Management (GSCM) has received growing attention in the last few years. Most of the automobile industries are setting up their own manufacturing plants in competitive Indian market. Due to public awareness, economic, environmental or legislative reasons, the requirement of GSCM has increased. In this context, this study aims to develop a structural model of the barriers to implement GSCM in Indian automobile industry.

Design/methodology/approach: We have identified various barriers and contextual relationships among the identified barriers. Classification of barriers has been carried out based upon dependence and driving power with the help of MICMAC analysis. In addition to this, a structural model of barriers to implement GSCM in Indian automobile industry has also been put forward using Interpretive Structural Modeling (ISM) technique.

Findings: Eleven numbers of relevant barriers have been identified from literature and subsequent discussions with experts from academia and industry. Out of which, five numbers of barriers have been identified as dependent variables; three number of barriers have been identified as the driver variables and three number of barriers have 
been identified as the linkage variables. No barrier has been identified as autonomous variable. Four barriers have been identified as top level barriers and one bottom level barrier. Removal of these barriers has also been discussed.

Research limitations/implications: A hypothetical model of these barriers has been developed based upon experts' opinions. The conclusions so drawn may be further modified to apply in real situation problem.

Practical implications: Clear understanding of these barriers will help organizations to prioritize better and manage their resources in an efficient and effective way.

Originality/value: Through this paper we contribute to identify the barriers to implement GSCM in Indian automobile industry and to prioritize them. The structured model developed will help to understand interdependence of the barriers. This paper also suggests the removal of these barriers.

Keywords: green supply chain management, barriers to implement GSCM, interpretive structural modeling

\section{Introduction}

Along with the rapid change in global manufacturing scenario, environmental and social issues are becoming more important in managing any business. Green supply Chain Management (GSCM) is an approach to improve performance of the process and products according to the requirements of the environmental regulations (Hsu \& Hu, 2008). GSCM has emerged in the last few years and covers all phases of product's life cycle from design, production and distribution phases to the use of products by the end users and its disposal at the end of product's life cycle (Borade \& Bansod, 2007). GSCM is integrating environmental thinking (Gilbert, 2000) into Supply Chain Management (SCM).Awareness level of customers of Green practices opted by organizations has got raised in India also. So organizations need to focus on the utilization of energy and resources for making environmentally sound supply chain. 
The objective of this paper is to identify various barriers to implement GSCM in Indian automobile industry, to indentify further the contextual relationship among the identified barriers to implement GSCM, to classify these barriers depending upon their driving and dependence power and finally to develop ISM based model of these barriers. ISM is a well established methodology for identifying relationship among specific item which define problem or an issue (Sage, 1977).

Section 2 consists of literature review of GSCM. Barriers to implement GSCM relevant to Indian automobile industry have been identified and described in section 3. Step wise elaborated procedure of interpretive structural modeling of these barriers to implement in Indian automobile industry follows in section 4 . Section 5 will help the readers to deal with these above said barriers to implement GSCM in Indian automobile industry efficiently and effectively. Conclusions, limitations of the study and scope of the future work have been discussed in subsequent sections.

\section{Green supply chain management (GSCM): literature review}

Green supply chain management (GSCM) involves traditional supply chain management practices integrating environmental criteria or concerns into organizational purchasing decision and long term relationships with suppliers (Gilbert, 2000). A green supply chains aims at confining the wastes within the industrial system in order to conserve energy and prevent the dissipation of dangerous materials into the environment (Torres, Nones, Morques, \& Evgenio, 2004). It recognizes the disproportionate environmental impact of supply chain processes within an organization. It recognizes the disproportionate environmental impact of supply chain processes within an organization. GSCM is the summing up of green purchasing, green manufacturing, green packing, green distribution and marketing. GSCM is to eliminate or minimize waste in the form of energy, emission, hazardous, chemical and solid waste (Olugu, Wong, \& Shaharoun, 2010).

Concepts and models related to environmental issues have been suggested by different researchers. Some of them have been described. Interpretive structural modeling(ISM) methodology was utilized to understand the mutual influences among the barriers so that those driving barriers, which can aggravate few more barriers and those independent barriers, which are mostly influenced by driving 
barriers are identified (Ravi \& Shankar, 2005) GSCM practices adopted by the electrical and electronic industry in Taiwan were investigated, which was dominated by original equipment manufacturing and original designing and manufacturing. The data was analyzed by using statistical package and the structural equation modeling (Chien \& Shih, 2007). Factors influencing to adopt green innovations for logistics service providers were described. The data generated from the questionnaire survey on logistics companies in Taiwan were used for modeling ( $Y u$ Lin \& Hui Ho, 2008). A proactive GSCM approach was suggested for improving environmental performance of processes and products in accordance with the requirements of environment regulations. This study examined the consistency approaches for factor analysis that determines the adoption and implementation of GSCM (Hsu \& Hu, 2008).

An increased attention for developing environmental management (EM) strategies for the supply chain was suggested. This study analyzed the interaction of criteria that was used to select the green suppliers based upon the environmental performance using ISM and Analytic Hierarchy Process (Kannan, Noorul Haq, Sasikumar, \& Arrununchchalam, 2008). ISM based model for greening the supply chain in Indian manufacturing industries was explained. Fifteen enablers were identified. A questionnaire based survey was conducted to rank these enablers. They found contextual relationships among enablers and developed hierarchy based model for the enablers by using ISM (Mudgal, Shankar, Talib, \& Raj, 2009). ISM based model for modeling the barriers of green supply chain Practices in Indian manufacturing industries was put forward. They suggested green businesses practices are not easy to adopt and implement due to the presence of many barriers. A questionnaire based survey was conducted to analyze and rank these barriers. Fifteen barriers were identified. ISM approach has been used to model and analyze key barriers (Mudgal, Shankar, Talib, \& Raj, 2010). Importance of GSCM and factors important to implement GSCM in Indian automobile industry was identified and described (Luthra, Manju, Kumar, \& Haleem, 2010).

\subsection{GSCM Vs conventional SCM}

GSCM and Conventional SCM differ in various ways. GSCM takes considerations to ecology as well as economy as an objective, while Conventional SCM is usually concentrated on economy as a single objective. GSCM are green, integrated and 
ecologically optimized, while Conventional SCM does not take into consideration human toxicological effects (Beamon, 1999; Gilbert, 2000; Ho Johnny, Shalishali, Maurice, Tseng, \& Ang, 2009). Conventional SCM concentrates more on controlling the final product; no matter harmful its effects are to the environment during production and distribution. Ecological requirements are key criteria for products and productions and at the same time the company must assure its economic sustainability by staying competitive and profitable (Ho Johnny, Shalishali, Maurice, Tseng, \& Ang, 2009). Differences between GSCM and SCM are summarized in Table 1.

\begin{tabular}{|c|c|c|c|c|}
\hline $\begin{array}{l}\text { S. } \\
\text { N. }\end{array}$ & Characteristics & $\begin{array}{l}\text { Green Supply } \\
\text { Chain } \\
\text { Management }\end{array}$ & $\begin{array}{l}\text { Conventional Supply } \\
\text { Chain Management }\end{array}$ & Researcher's \\
\hline 1 & Objectives & $\begin{array}{l}\text { Ecological and } \\
\text { Economic }\end{array}$ & Economic & \multirow{6}{*}{$\begin{array}{l}\text { Beamon (1999) } \\
\text { Gilbert (2000) } \\
\text { Ho Johnny et al. } \\
\text { (2009) }\end{array}$} \\
\hline 2 & $\begin{array}{l}\text { Ecological } \\
\text { Optimization }\end{array}$ & $\begin{array}{l}\text { High Ecological } \\
\text { Impacts }\end{array}$ & $\begin{array}{l}\text { Integrated Approach } \\
\text { Low ecological impacts }\end{array}$ & \\
\hline 3 & $\begin{array}{l}\text { Supplier Selection } \\
\text { criteria }\end{array}$ & $\begin{array}{l}\text { Eco logical Aspects } \\
\text { Long Term } \\
\text { relationship }\end{array}$ & $\begin{array}{l}\text { Price Switching suppliers } \\
\text { quickly } \\
\text { Short term relationship }\end{array}$ & \\
\hline 4 & Cost Pressure & High & Low & \\
\hline 5 & Flexibility & Low & High & \\
\hline 6 & Speed & low & High & \\
\hline
\end{tabular}

Table 1. “Difference between the Green Supply Chain Management and Conventional Supply Chain Management".

\section{Barriers to implement GSCM in Indian automobile industry}

According to world statistics, the automobile industry is world's largest single manufacturing sector (Lettice, Wyatt, \& Evans, 2010).The growth in the world's population has also heightened the demand for the vehicles (Olugu, Wong, \& Shaharoun, 2010). Increasing trend of demand of automobiles such as cars, bikes and commercial vehicles in India has been noticed in last few years, therefore leading international and domestic automobile manufacturers (like Maruti Suzuki, Hyundai, Tata Motors, General Motors, Honda, Fiat, Bajaj Auto, Hero Honda etc.) are either setting up their new manufacturing plants or increasing their production capacity in their existing plants in India.

Environmental issues have become more relevant in India. So companies need to focus on energy and resources for making environmentally sound supply chain. 
Economics, environmental or legislative reasons have increased the requirement of GSCM in Indian Automobile industry.

We have identified various barriers to implement GSCM in Indian automobile industry from the literature reviews and expert opinions. Literature was reviewed to identify barriers to implement GSCM in Indian automobile industry. We conducted a workshop, in which different experts from academia and industry were invited. Four were from industry and two were from academia. Brainstorming session was conducted and eleven barriers relevant to Indian automobile industry were identified. These barriers to implementation of GSCM in Indian Automobile industry are: Lack of IT Implementation; Resistance to Technology Advancement Adoption; Lack of Organization Encouragement; Poor Quality of Human Resources; Market Competition and Uncertainty; Lack of Government Support System; Lack of Implementing Green Practices; Lack of Top Management Commitment; Cost Implications; Supplier Reluctance to Change towards GSCM and Unawareness of customers. Again brainstorming session was conducted to reach consensuses about the contextual relationships (pair wise) to form a structural self interaction matrix (elaborated in section 4). The above said identified barriers are explained as:

\subsection{Lack of IT implementation}

IT systems support collaborative supply chain processes and enhance supply chain performance (Rogers et al., 1998). An efficient information and technology system is very necessary for supporting the GSCM during various stages of product life cycle. It can be very useful for product development programs encompassing the design for the environment, recovery and reuse. Efficient information systems are needed for tracking and tracing the returns of product, linking with the previous sales (Ravi \& Shankar, 2005) Information support is necessary for developing linkages to achieve efficient GSCM in automobile industry. It is required to handle information's flows associated with both forward and backward flow of materials and other resources to manage green SC efficiently (AlKhidir \& Zailani, 2009). Also, IT enablement reduces lot of paper usage, which supports GSCM philosophy. So, lack of IT implementation is an important barrier to achieve efficient GSCM. 


\subsection{Resistance to technology advancement adoption}

Technology is a kind of knowledge. An organization with rich experiences in the application and adoption of related technologies will have higher ability in technological innovation (Gant, 1996). An organization will have higher innovative capability when knowledge can be shared more easily within the organization (TSai \& Ghoshal, 1999). Technological advancement can be achieved with higher transferability. It is easy to share technological transfer or share technological knowledge with higher explicitness (Cooper, 1994). Innovation and technology incorporate the innovation into corporate culture, encouraging new ideas and processes and solutions by all the employees of the firm (Digalwar \& Metri, 2004). Resistance of organizations to technology advancement adoption is the resistance to change. An organizational barrier means difficulty of implementing fundamental change in the organization. This is especially true when there are changes in the core features of organizations like organizational goals, forms of authority, core technology, operational strategy and market strategy (AlKhidir \& Zailani, 2009). Therefore, resistance to technology advancement adoption is important barrier to implement GSCM in automobile industry.

\subsection{Lack of organizational encouragement}

Informal linkages and improved communication help the organizations to adopt Green's practices (Yu Lin \& Hui Ho, 2008). Training and education are the prime requirements for achieving successful implementation of GSCM in any organization (Ravi \& Shankar, 2005). Management may encourage employees to learn green information. Organizations may provide rewards for green employees. Employees may be helped when they face green problems and may be provided support to learn green information (Hsu \& Hu, 2008).

\subsection{Poor quality of human resources}

A Company with higher quality of human resources such as better training or education will help in implementing Green Supply Chain Management. Quality human resources can provide new ideas for companies, learn new technologies easily, share knowledge with each other and use new technologies to solve problem (Yu Lin \& Hui Ho, 2008).However, due to financial constraint; quality of 
human resources is barrier. Therefore poor quality of human resources is an important barrier to implement GSCM in Indian automobile industry.

\subsection{Market competition and uncertainty}

In today's scenario market uncertainty is very high due to global competitiveness, and customer's requirements (Yu Lin, 2007). Research and benchmarked global competitors develop and deploy strategies. The external environment in which a firm conducts its business will also influence the innovative capability as well as intention to adopt innovations (Hosseini, 2007). We assume that market competition and uncertainty is most important barrier to achieve GSCM in Indian automobile industry.

\subsection{Lack of Government support systems}

Government regulation can encourage or discourage the adoption of innovation, as Government sets the environmental regulations for industry (Scupola, 2003). Time consuming regulatory requirements, fees or levies may discourage smaller firms. Tax structures that distort incentives can discourage industry to implement GSCM. Government institutions are considered as barriers to development in the environmental management in the sense that institutional process for implementing GSCM are going on but very limited institutional support is given for new ideas to implement GSCM. The tendency of government to encourage old practices is major barrier (AlKhidir \& Zailani, 2009). Therefore lack of government support systems is a barrier to implement efficient GSCM in Indian automobile industry.

\subsection{Lack of implementing green practices}

Innovative green practices are associated with the explicitness of green practices, accumulation of green related knowledge, organizational encouragement and quality of human resources (Yu Lin \& Hui Ho, 2008). Innovative green practices involves hazardous solid waste disposal, energy conservation, reusing and recycling of materials. Innovative green practices promote innovative design, new market opportunities and makes their quality better than others. However, due to market competition and cost implications, organizations try to save cost. Implementing GSCM practices initially involves high investment. Financial 
constraints also lead to resistance to implementing green practices (Ravi \& Shankar, 2005).From the above discussion; we expect that lack of implementation of green practices is the most important barrier to implement efficient GSCM in Indian automobile industry.

\subsection{Lack of top management commitment}

Top management support and commitment is necessary for any strategic program success (Hamel \& Prahalad, 1989; Zhu \& Sarkis, 2007). Top Management support is especially useful for environmental practices such as GSCM. Top management has significant ability to influence, support actual formation and implementation of green initiatives across the organization (Sarkis, 2009).Top management provides continuous support for GSCM in the strategic plans and action plans for successfully implementing them (Ravi \& Shankar, 2005). Therefore, we assume that lack of top management commitment is one of the barriers to implement of GSCM in Indian automobile industry.

\subsection{Cost implications}

Historically, cost has been used as the prime performance measure. Usually, high cost is a big pressure in GSCM as compared to conventional SCM. The initial investment requirement by green methodologies such as green design, green manufacturing, green labeling of packing etc. are too high. Engaging in environmental management involves two types of costs, direct cost and transaction cost. Both types of costs are likely to constitute significant barrier to implement GSCM (AIKhidir \& Zailani, 2009). IT enablement, Technology advancement adoption, hiring good quality of employees, motivating and training of employees towards GSCM will require high initial investment. Therefore, cost implication is a major barrier among the barriers to implement efficient GSCM in Indian automobile industry.

\subsection{Supplier reluctance to change towards GSCM}

Strengthen relationships with suppliers result in lower inventory levels, costs and higher accuracy. Involvement of the suppliers in design process and technology affects overall performance of whole chain (Sarkar \& Mohapatra, 2006). Suppliers' reluctance to change towards GSCM is due to traditional mindset and suppliers' 
interests being different from those of the total network (Mudgal et al., 2010). Supplier manufacturer relationships are considered most important for developing competitive advantage for the manufacturer. Large automobile industries have normally 2000 to 3000 suppliers. The manufacturers cannot produce green products unless they work together with suppliers. Suppliers need to meet the requirement of buyers to maintain business relationship. So we can say that Supplier reluctance to change towards GSCM is a very important barrier to implement GSCM in Indian automobile industry.

\subsection{Unawareness of customers}

A major barrier of GSCM seen in Indian automobile industry is lack of awareness of customers about the benefits of green products. Customer demands become most crucial type of external pressure. Customer's awareness means if customer demands green products; the company has to change technology and organization for innovative green products. But in Indian automobile market, due to unawareness of customers towards green product benefits, automobile producers are producing non green products. In U.S.A., an estimated $75 \%$ of consumers claim that their purchases are influenced by reputation and $80 \%$ would be willing to pay more for environment friendly products (Lamming \& Hmapson, 1996). Thus, we can say that unawareness of customers is a major barrier to implement GSCM in Indian automobile industry.

Above said barriers to implement GSCM in Indian automobile industry have been summarized in Table 2.

\section{Interpretive structural modeling applied to barriers to implement of GSCM in Indian automobile industry}

Interpretive Structural Modeling (ISM) is a methodology used to indentify relationship among specific items, which define a problem or issue; it was firstly developed in 1970's (Warfield, 1974; Sage, 1977).ISM is interpretive as judgment of the selected group for the study decides whether and how the variables are related. ISM generally has following steps (Ravi \& Shankar, 2005): 


\begin{tabular}{|c|c|c|c|}
\hline S.N. & $\begin{array}{l}\text { Barrier to } \\
\text { I mplement } \\
\text { GSCM }\end{array}$ & Description & Researcher's \\
\hline 1 & $\begin{array}{l}\text { Lack of IT } \\
\text { Implementation }\end{array}$ & $\begin{array}{l}\text { Lack of IT Implementation means } \\
\text { non implementation I nformation } \\
\text { Technology resources like } \\
\text { computers, internet etc. Slow, } \\
\text { ineffective and improper } \\
\text { communication is due to lack of IT } \\
\text { I mplementation. }\end{array}$ & $\begin{array}{l}\text { Rogers et al. (1998); Wu et al. } \\
\text { (2009); Ravi et al. (2005); } \\
\text { AlKhidir et al. (2009); Mclaren et } \\
\text { al. (2004). }\end{array}$ \\
\hline 2 & $\begin{array}{l}\text { Resistance to } \\
\text { Technology } \\
\text { Advancement } \\
\text { Adoption }\end{array}$ & $\begin{array}{l}\text { Resistance to Technology } \\
\text { advancement adoption is not doing } \\
\text { advancements in machinery and } \\
\text { equipments to improve the } \\
\text { products. }\end{array}$ & $\begin{array}{l}\text { Hosseini (2007); Cooper (1994); } \\
\text { Hsu et al. (2008); Digalwar et al. } \\
\text { (2004); Gant (1996); TSai et al. } \\
\text { (1999); AlKhidir et al. (2009). }\end{array}$ \\
\hline 3 & $\begin{array}{l}\text { Lack of } \\
\text { Organization } \\
\text { Encouragement }\end{array}$ & $\begin{array}{l}\text { Lack of Organization } \\
\text { Encouragement is not motivating } \\
\text { the employees towards GSCM. }\end{array}$ & $\begin{array}{l}\text { Yu Lin (2007); Yu Lin et al. } \\
\text { (2008); Hsu et al. (2008); Chien } \\
\text { et al. (2007); Ravi et al. (2005). }\end{array}$ \\
\hline 4 & $\begin{array}{l}\text { Lack of Quality of } \\
\text { Human Resources }\end{array}$ & $\begin{array}{l}\text { Lack of Quality of human resources } \\
\text { means not recruiting well qualified } \\
\text { and professionals. }\end{array}$ & $\begin{array}{l}\text { Yu Lin (2007); Yu Lin et al. } \\
\text { (2008); Hsu et al. (2008); Chien } \\
\text { et al. (2007). }\end{array}$ \\
\hline 5 & $\begin{array}{l}\text { Market } \\
\text { Competition and } \\
\text { Uncertainty }\end{array}$ & $\begin{array}{l}\text { Market Competition and } \\
\text { Uncertainty is very high due to } \\
\text { global competitiveness, and } \\
\text { varying customer's requirements }\end{array}$ & $\begin{array}{l}\text { Hosseini (2007); Yu Lin (2007); } \\
\text { Mudgal et al. (2010). }\end{array}$ \\
\hline 6 & $\begin{array}{l}\text { Lack of } \\
\text { Government } \\
\text { Support systems }\end{array}$ & $\begin{array}{l}\text { Lack of Government support } \\
\text { systems means Government not } \\
\text { making industry friendly policies } \\
\text { toward GSCM and not giving } \\
\text { special benefits to those } \\
\text { organizations implementing GSCM. }\end{array}$ & $\begin{array}{l}\text { Hosseini (2007); Yu Lin et al. } \\
\text { (2008); Hsu et al. (2008); Mudgal } \\
\text { et al. (2009); Mudgal et al. } \\
\text { (2010); Scupola (2003); } \\
\text { Srivastva (2007). }\end{array}$ \\
\hline 7 & $\begin{array}{l}\text { Lack of } \\
\text { Implementing } \\
\text { Green Practices }\end{array}$ & $\begin{array}{l}\text { Lack of Innovative Green Practices } \\
\text { means not taking consideration of } \\
\text { practices like hazardous solid } \\
\text { waste disposal, energy } \\
\text { conservation, reusing and recycling } \\
\text { materials etc. }\end{array}$ & $\begin{array}{l}\text { Yu Lin et al. (2008); Hsu et al. } \\
\text { (2008); Mudgal et al. (2009); } \\
\text { Ravi et al. (2005). }\end{array}$ \\
\hline 8 & $\begin{array}{l}\text { Lack of Top } \\
\text { Management } \\
\text { Commitment }\end{array}$ & $\begin{array}{l}\text { Lack of Top Management } \\
\text { Commitment means that top } \\
\text { management not showing interests } \\
\text { in green practices. }\end{array}$ & $\begin{array}{l}\text { Digalwar et al. (2004); Hamel et } \\
\text { al. (1989); Sarkis (2009); Mudgal } \\
\text { et al. (2009); Mudgal et al. } \\
\text { (2010); Ravi V. et al. (2005); } \\
\text { Zhu (2007). }\end{array}$ \\
\hline 9 & Cost Implications & $\begin{array}{l}\text { The high investment requirement } \\
\text { by green Methodologies such as } \\
\text { green design, green } \\
\text { manufacturing, green labeling of } \\
\text { packing etc. }\end{array}$ & $\begin{array}{l}\text { Hosseini (2007); Mudgal et al. } \\
\text { (2009); Ravi et al. (2005); } \\
\text { AlKhidir et al. (2009). }\end{array}$ \\
\hline 10 & $\begin{array}{l}\text { Supplier } \\
\text { Reluctance to } \\
\text { change towards } \\
\text { GSCM }\end{array}$ & $\begin{array}{l}\text { Supplier reluctance to change } \\
\text { towards GSCM means not } \\
\text { involvement of the suppliers in } \\
\text { design process and technology, } \\
\text { which affects overall performance } \\
\text { of whole chain. }\end{array}$ & $\begin{array}{l}\text { Hsu et al. (2008); Kannan et al. } \\
\text { (2008); Lettice et al. (2010); Ravi } \\
\text { et al. (2005); Srivastva (2007); } \\
\text { Sarkar et al. (2006). }\end{array}$ \\
\hline 11 & $\begin{array}{l}\text { Unawareness of } \\
\text { customers }\end{array}$ & $\begin{array}{l}\text { Unawareness of Customers means } \\
\text { that customers do not know about } \\
\text { green products and their benefits. }\end{array}$ & $\begin{array}{l}\text { Lamming et al. (1996); Mudgal et } \\
\text { al. (2009); Ravi et al. (2005); } \\
\text { Zhu et al. (2004); Zhu et al. } \\
\text { (2007); Zhu et al. (2008). }\end{array}$ \\
\hline
\end{tabular}

Table 2. "Barrier to Implement GSCM in Indian Automobile Industry reported in Literature". 
- Step 1:- Variables affecting the system are listed; in our research work barriers to implement GSCM in Indian automobile industry have been identified as variables.

- Step 2:- From the variables identified in step 1, contextual relationship among the variables with respect to which pairs of variables are examined.

- Step 3:- A Structural Self-Interaction Matrix (SSIM) is developed for variables, which indicates pair wise relationship among variables of the system under consideration.

- Step 4:- A reachability matrix is developed from the SSIM and the matrix is checked for transitivity. The transitivity of the contextual relationships is a basic assumption made in ISM. It states that if variable $A$ is related to variable $B$ and variable $B$ is related to variable $C$, then variable $A$ is necessarily related to variable $C$.

- Step 5:- The reachability matrix obtained in Step 4 is partitioned into different levels.

- Step 6:- Based on the contextual relationships in the reachability matrix, a directed graph is drawn and the transitive links are removed.

- Step 7:- The resultant diagraph is converted into an Interpretive Structural Model by replacing variable nodes with statements.

\subsection{Data gathering methodology and structural self-interaction matrix}

As discussed in section 3, experts from industry and the academia were consulted during the workshop conducted to identify the nature of contextual relationships among the barriers to implement GSCM in Indian automobile industry. In developing SSIM, following four symbols have been used to denote the direction of relationship between two barriers $\mathrm{i}$ and $\mathrm{j}$.

V- Barrier i will lead to barrier j;

A- Barrier $\mathrm{j}$ will lead to barrier $\mathrm{i}$;

X- Barrier $\mathrm{i}$ and $\mathrm{j}$ will lead to each other; 
O- Barrier $\mathrm{i}$ and $\mathrm{j}$ are unrelated

Based on the contextual relationships, the SSIM has been developed (Table 3). Barrier 1 leads to barrier 7 so symbol ' $V$ ' has been given in the cell $(1,7)$; barrier 2 leads to barrier 8 so symbol ' $A$ ' has been given in the cell $(2,8)$; barrier 5 and 7 lead to each other so symbol ' $X$ ' has been given in the cell $(2,8)$; barrier 3 and 11 do not lead to each other so symbol ' $O$ ' has been given in the cell $(3,11)$ and so on. The number of pair wise comparison question addressed for developing the SSIM are $((\mathrm{N}) *(\mathrm{~N}-1) / 2)$, where $\mathrm{N}$ is the number of barriers.

\begin{tabular}{|c|c|c|c|c|c|c|c|c|c|c|c|}
\hline \multirow{2}{*}{ S. } & \multirow[t]{2}{*}{ Barrier to I mplement GSCM } & \multicolumn{10}{|c|}{ Barrier Number } \\
\hline & & 11 & 10 & 9 & 8 & 7 & 6 & 5 & 4 & 3 & 2 \\
\hline 1 & Lack of IT I mplementation & $\mathrm{O}$ & $\mathrm{O}$ & V & A & V & $\mathrm{O}$ & $\mathrm{O}$ & $\mathrm{V}$ & $\mathrm{O}$ & $\mathrm{V}$ \\
\hline 2 & $\begin{array}{l}\text { Resistance to Technology } \\
\text { Advancement Adoption }\end{array}$ & $x$ & V & V & A & V & A & $\mathrm{v}$ & $x$ & $\mathrm{~V}$ & $x$ \\
\hline 3 & Lack of Organization Encouragement & $\mathrm{O}$ & $\mathrm{V}$ & $\mathrm{V}$ & A & $\mathrm{V}$ & A & $\mathrm{V}$ & $\mathrm{V}$ & $\mathrm{X}$ & \\
\hline 4 & Lack of Quality of Human Resources & $\mathrm{O}$ & $\mathrm{V}$ & $\mathrm{V}$ & A & $\mathrm{V}$ & $\mathrm{O}$ & $\mathrm{V}$ & $\mathrm{X}$ & & \\
\hline 5. & Market Competition and Uncertainty & $\mathrm{O}$ & $\mathrm{O}$ & $\mathrm{V}$ & $\mathrm{O}$ & $\bar{X}$ & $\mathrm{O}$ & $\bar{X}$ & & & \\
\hline 6 & Lack of Government Support Policies & $\mathrm{V}$ & $\mathrm{V}$ & $\mathrm{V}$ & $\mathrm{V}$ & $\mathrm{V}$ & $\mathrm{X}$ & & & & \\
\hline 7 & Lack of Implementing Green Practices & $\mathrm{X}$ & A & A & $\mathrm{V}$ & $\mathrm{X}$ & & & & & \\
\hline 8 & $\begin{array}{l}\text { Lack of Top Management } \\
\text { Commitment }\end{array}$ & $\mathrm{O}$ & V & $\mathrm{O}$ & $\mathrm{x}$ & & & & & & \\
\hline 9 & Cost Implications & $\mathrm{X}$ & A & $\mathrm{X}$ & & & & & & & \\
\hline $\begin{array}{l}1 \\
0\end{array}$ & $\begin{array}{l}\text { Supplier Reluctance to change } \\
\text { towards GSCM }\end{array}$ & $\mathrm{O}$ & $x$ & & & & & & & & \\
\hline $\begin{array}{l}1 \\
1\end{array}$ & Unawareness of customers & $\mathrm{x}$ & & & & & & & & & \\
\hline
\end{tabular}

Table 3. "Structured Self Intersection Matrix (SSIM) for Barriers to Implement GSCM in Indian Automobile Industry".

\subsection{Reachability matrix}

The SSIM has been converted in to a binary matrix, named Initial Reachability Matrix by substituting $V, A, X, O$ by 1 or 0 applying following rules:

- If $(i, j)$ value in the SSIM is $V,(i, j)$ value in the reachability matrix will be 1 and $(j, i)$ value will be 0 ; for $V(1,7)$ in SSIM, ' 1 ' has been given in cell $(1,7)$ and ' 0 ' in cell $(7,1)$ in initial reachability matrix.

- If $(i, j)$ value in the SSIM is $A,(i, j)$ value in the reachability matrix will be 0 and $(j, i)$ value will be 1 ; for $A(2,8)$ in SSIM, ' 0 ' has been given in cell $(2,8)$ and ' 1 ' in cell $(8,2)$ in initial reachability matrix. 


\begin{tabular}{|c|l|c|c|c|c|c|c|c|c|c|c|c|}
\hline $\begin{array}{c}\text { S. } \\
\mathbf{N} .\end{array}$ & Barrier to I mplement GSCM & $\mathbf{1}$ & $\mathbf{2}$ & $\mathbf{3}$ & $\mathbf{4}$ & $\mathbf{5}$ & $\mathbf{6}$ & $\mathbf{7}$ & $\mathbf{8}$ & $\mathbf{9}$ & $\mathbf{1 0}$ & $\mathbf{1 1}$ \\
\hline 1 & Lack of IT Implementation & 1 & 1 & 0 & 1 & 0 & 0 & 1 & 0 & 1 & 0 & 0 \\
\hline 2 & $\begin{array}{l}\text { Resistance to Technology Advancement } \\
\text { Adoption }\end{array}$ & 0 & 1 & 1 & 1 & 1 & 0 & 1 & 0 & 1 & 1 & 0 \\
\hline 3 & Lack of Organization Encouragement & 0 & 0 & 1 & 1 & 1 & 0 & 1 & 0 & 1 & 1 & 0 \\
\hline 4 & Lack of Quality of Human Resources & 0 & 1 & 0 & 1 & 1 & 0 & 1 & 0 & 1 & 1 & 0 \\
\hline 5 & Market Competition and Uncertainty & 0 & 0 & 0 & 0 & 1 & 0 & 1 & 0 & 1 & 0 & 1 \\
\hline 6 & Lack of Government Support Policies & 0 & 1 & 1 & 0 & 0 & 1 & 1 & 1 & 1 & 1 & 1 \\
\hline 7 & Lack of Implementing Green Practices & 0 & 0 & 0 & 0 & 1 & 0 & 1 & 0 & 0 & 0 & 1 \\
\hline 8 & Lack of Top Management Commitment & 1 & 1 & 1 & 1 & 0 & 0 & 1 & 1 & 0 & 1 & 0 \\
\hline 9 & Cost Implications & 0 & 0 & 0 & 0 & 0 & 0 & 1 & 0 & 1 & 0 & 1 \\
\hline 10 & Supplier Reluctance to change towards GSCM & 0 & 0 & 0 & 0 & 0 & 0 & 1 & 0 & 1 & 1 & 0 \\
\hline 11 & Unawareness of customers & 0 & 0 & 0 & 0 & 0 & 0 & 1 & 0 & 1 & 0 & 1 \\
\hline
\end{tabular}

Table 4. "I nitial Reachability Matrix for Barriers to Implement GSCM in Indian Automobile Industry".

\begin{tabular}{|c|c|c|c|c|c|c|c|c|c|c|c|c|c|}
\hline $\begin{array}{l}\text { S. } \\
\text { N. }\end{array}$ & $\begin{array}{l}\text { Barrier to I mplement } \\
\text { GSCM }\end{array}$ & 1 & 2 & 3 & 4 & 5 & 6 & 7 & 8 & 9 & 10 & 11 & $\begin{array}{l}\text { Driving } \\
\text { power }\end{array}$ \\
\hline 1 & $\begin{array}{l}\text { Lack of IT } \\
\text { Implementation }\end{array}$ & 1 & 1 & $1^{*}$ & 1 & 1* & 0 & 1 & 0 & 1 & 1* & 1* & 09 \\
\hline 2 & $\begin{array}{l}\text { Resistance to } \\
\text { Technology } \\
\text { Advancement Adoption }\end{array}$ & 0 & 1 & 1 & 1 & 1 & 0 & 1 & 0 & 1 & 1 & 1* & 08 \\
\hline 3 & $\begin{array}{l}\text { Lack of Organization } \\
\text { Encouragement }\end{array}$ & 0 & 1 & 1 & 1 & 1 & 0 & 1 & 0 & 1 & 1 & $1^{*}$ & 08 \\
\hline 4 & $\begin{array}{l}\text { Lack of Quality of Human } \\
\text { Resources }\end{array}$ & 0 & 1 & 1 & 1 & 1 & 0 & 1 & 0 & 1 & 1 & 1* & 08 \\
\hline 5 & $\begin{array}{l}\text { Market Competition and } \\
\text { Uncertainty }\end{array}$ & 0 & 0 & 0 & 0 & 1 & 0 & 1 & 0 & 1 & 0 & 1 & 04 \\
\hline 6 & $\begin{array}{l}\text { Lack of Government } \\
\text { Support Policies }\end{array}$ & 1* & 1 & 1 & $1^{*}$ & $1 *$ & 1 & 1 & 1 & 1 & 1 & 1 & 11 \\
\hline 7 & $\begin{array}{l}\text { Lack of Implementing } \\
\text { Green Practices }\end{array}$ & 0 & 0 & 0 & 0 & 1 & 0 & 1 & 0 & 1* & 0 & 1 & 04 \\
\hline 8 & $\begin{array}{l}\text { Lack of Top Management } \\
\text { Commitment }\end{array}$ & 1 & 1 & 1 & 1 & 1* & 0 & 1 & 1 & 1* & 1 & $1 *$ & 10 \\
\hline 9 & Cost Implications & 0 & 0 & 0 & 0 & $1 *$ & 0 & 1 & 0 & 1 & 0 & 1 & 04 \\
\hline 10 & $\begin{array}{l}\text { Supplier Reluctance to } \\
\text { change towards GSCM }\end{array}$ & 0 & 0 & 0 & 0 & $1 *$ & 0 & 1 & 0 & $1 *$ & 1 & 1 & 05 \\
\hline 11 & $\begin{array}{l}\text { Unawareness of } \\
\text { customers }\end{array}$ & 0 & 0 & 0 & 0 & $1 *$ & 0 & 1 & 0 & 1 & 0 & 1 & 04 \\
\hline & Dependence Power & 03 & 06 & 06 & 06 & 11 & 01 & 11 & 02 & 11 & 07 & 11 & $75 / 75$ \\
\hline
\end{tabular}

Table 5. "Final Reachablility Matrix for Barriers to Implement GSCM in Indian Automobile Industry". 
- If $(i, j)$ value in the SSIM is $X,(i, j)$ value in the reachability matrix will be 1 and $(j, i)$ value will also be 1 ; for $X(5,7)$ in SSIM, ' 1 ' has been given in cell $(5,7)$ and ' 1 ' in cell $(7,5)$ also in initial reachability matrix.

- If $(i, j)$ value in the SSIM is $O,(i, j)$ value in the reachability matrix will be 0 and $(j, i)$ value will also be 0 ; for $O(3,11)$ in SSIM, ' 0 ' has been given in cell $(3,11)$ and ' 0 ' in cell $(11,3)$ also in initial reachability matrix.

By applying these rules, an initial reachability matrix for the barriers to implement GSCM has been obtained (Table 4). The final reachabilty matrix has been obtained by adding transitivity as explained in Step 4 earlier (Table 5). The driving power and the dependence power of each barrier have also been shown in the Table 5 .

\subsection{Partitioning of levels}

\begin{tabular}{|c|l|l|l|l|}
\hline $\begin{array}{c}\text { Barrier } \\
\text { S. N. }\end{array}$ & Reachability Set & Antecedent Set & I ntersection & Level \\
\hline 1 & $1,2,3,4,5,7,9,10,11$ & $1,6,8$ & 1 & \\
\hline 2 & $2,3,4,5,7,9,10,11$ & $1,2,3,4,6,8$ & $2,3,4$ & \\
\hline 3 & $2,3,4,5,7,9,10,11$ & $1.2 .3,4.6 .8$ & $2,3,4$ & \\
\hline 4 & $2,3,4,5,7,9,10,11$ & $1,2,3,4,6,8$ & $2,3,4$ & 1 st \\
\hline 5. & $5,7,9,11$ & $1,2,3,4,5,6,7,8,9,10,11$ & $5,7,9,11$ & \\
\hline 6 & $1,2,3,4,5,6,7,8,9,10,11$ & 6 & 6 & 1 st \\
\hline 7 & $5,7,9,11$ & $1,2,3,4,5,6,7,8,9,10,11$ & $5,7,9,11$ & \\
\hline 8 & $1,2,3,4,5,7,8,9,10,11$ & 6,8 & 8 & 1 st \\
\hline 9 & $5,7,9,11$ & $1,2,3,4,5,6,7,8,9,10,11$ & $5,7,9,11$ & \\
\hline 10 & $5,7,9,10,11$ & $1,2,3,4,6,8,10$ & 10 & 1 st \\
\hline 11 & $5,7,9,11$ & $1,2,3,4,5,6,7,8,9,10,11$ & $5,7,9,11$ & \\
\hline
\end{tabular}

Table 6. "First Iteration to FIND LEVELS of Barriers to Implement GSCM in Indian Automobile Industry".

The reachability and antecedent set (Warfield, 1974) for each barrier have been determined from the final reachability matrix. The reachability set for a barrier consists of the barrier itself and the other barriers, which it influences. The antecedent set consists of the barrier itself and other barriers, which may influence it. Reachability and Antecedent set and Intersection sets are found for the all 
barriers. Barrier having same reachability set and the intersection set is assigned as top level barrier in the ISM hierarchy or Level 1 is shown in Table 6.After finding Level 1 , it is then discarded for finding further Levels. The iterative procedure is continued until Level of each barrier is found. We have indentified six levels in our study. Market competition and uncertainty; Lack of implementing Green Practices; Cost implications; Unawareness of customers have been identified as top level barriers and Lack of government support systems has been identified as most important Bottom level barrier.

\subsection{Barriers classification}

Variables are classified in to four clusters (Mandal \& Deshmukh, 1994) named autonomous variables, dependent variables, linkage variables and independent variables. Autonomous variables (first cluster) have weak driving power and dependence. These variables can be disconnected from the system. In our study, no barrier lies in this range. The second cluster is named dependent variables. They have weak driving power and strong dependence power. In our study, five barriers named market competition and uncertainty; Lack of implementing green Practices, cost implications, unawareness of customers and supplier reluctance to change towards $\operatorname{GSCM}(5,7,9,11$ and 10) are lying in this range. The third cluster named linkage variables having strong driving power and strong dependence power. In our study, barriers named Resistance to technology advancement adoption, Lack of organization encouragement and Poor quality of human resources $(2,3$ and 4$)$ are lying in this range. The fourth cluster named independent variables has strong driving power and weak dependence power. In our study, three barriers named Lack of government support systems, Lack of top management commitment and Lack of IT implementation (6, 8 and 1) are lying in this range. The graph between dependence power and driving power for the barriers to implement GSCM in Indian automobile industry is given in Figurel. 


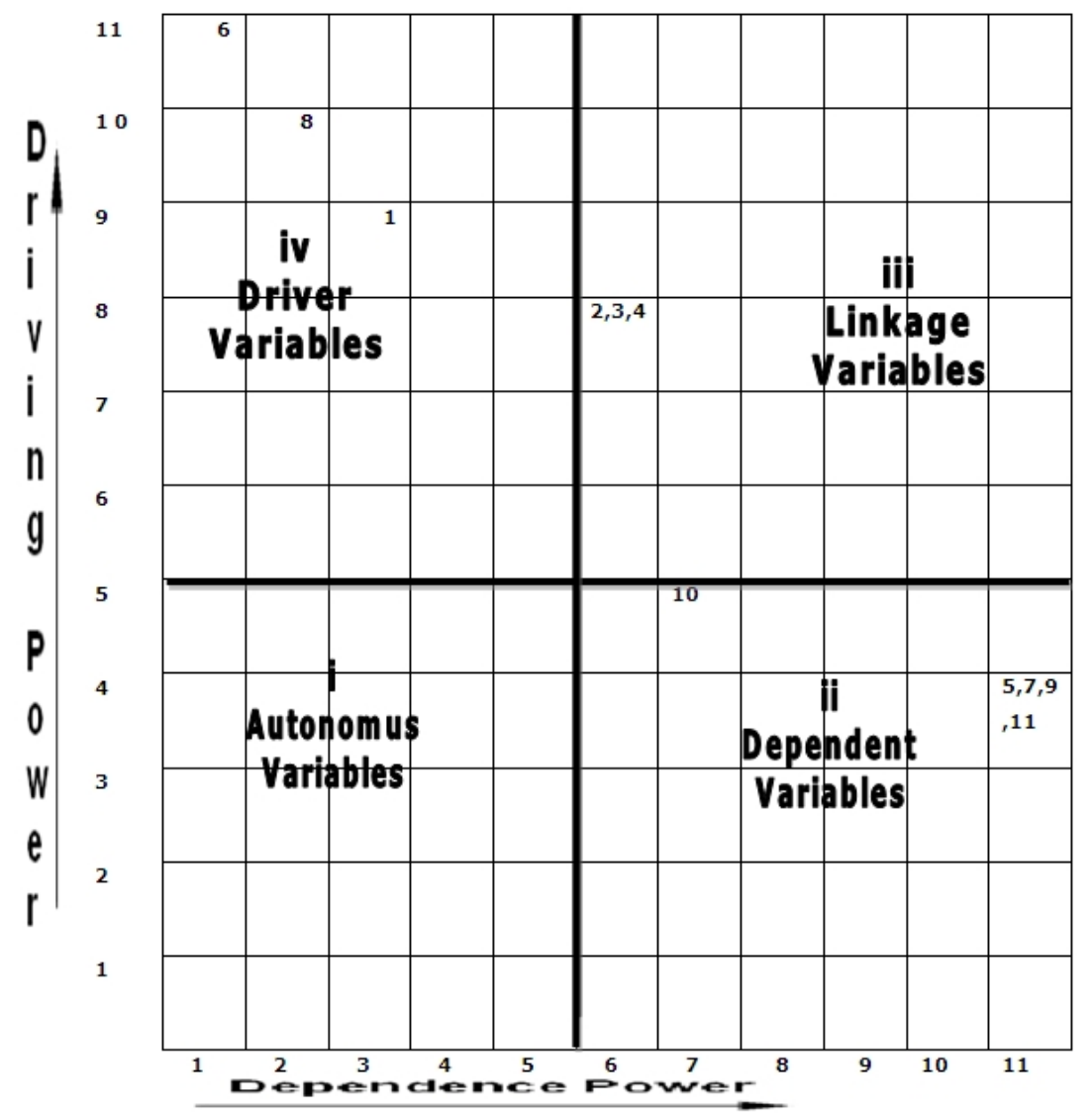

Figure 1. "Cluster of Barriers to Implement GSCM in Indian Automobile industry".

The objective of this study is to analyze the driving power and the dependency power of barriers (Jharkharia \& Shankar, 2005). Higher dependence values for a factor means a large number of barriers to be addressed before its removal and high driving value of a barrier means a large number of barriers that could be removed by its removal

\subsection{ISM model formulation}

Once all levels are found, these levels have been summarized in the Table 7. Market competition and uncertainty; Lack of implementing Green Practices, Cost implications, Unawareness of customers and Supplier reluctance to change towards GSCM are dependent variables. Lack of government support systems, Lack of top management commitment and Lack of IT implementation are the driver variables. Resistance to technology advancement adoption, Lack of organization encouragement and Poor quality of human resources are the linkage variables. No 
barrier is autonomous variable. From the final reachability matrix (Table 4), the structural model is generated by vertices and edges (Jharkharia \& Shankar, 2005).This graph is called digraph as shown in Figure 2. After removing the transitivity's as described in the ISM methodology, ISM Model has been made as shown in Figure 3. Market competition and uncertainty; Lack of implementing Green Practices, Cost implications, Unawareness of customers are found top level barriers and Lack of government support systems is found bottom level barrier.

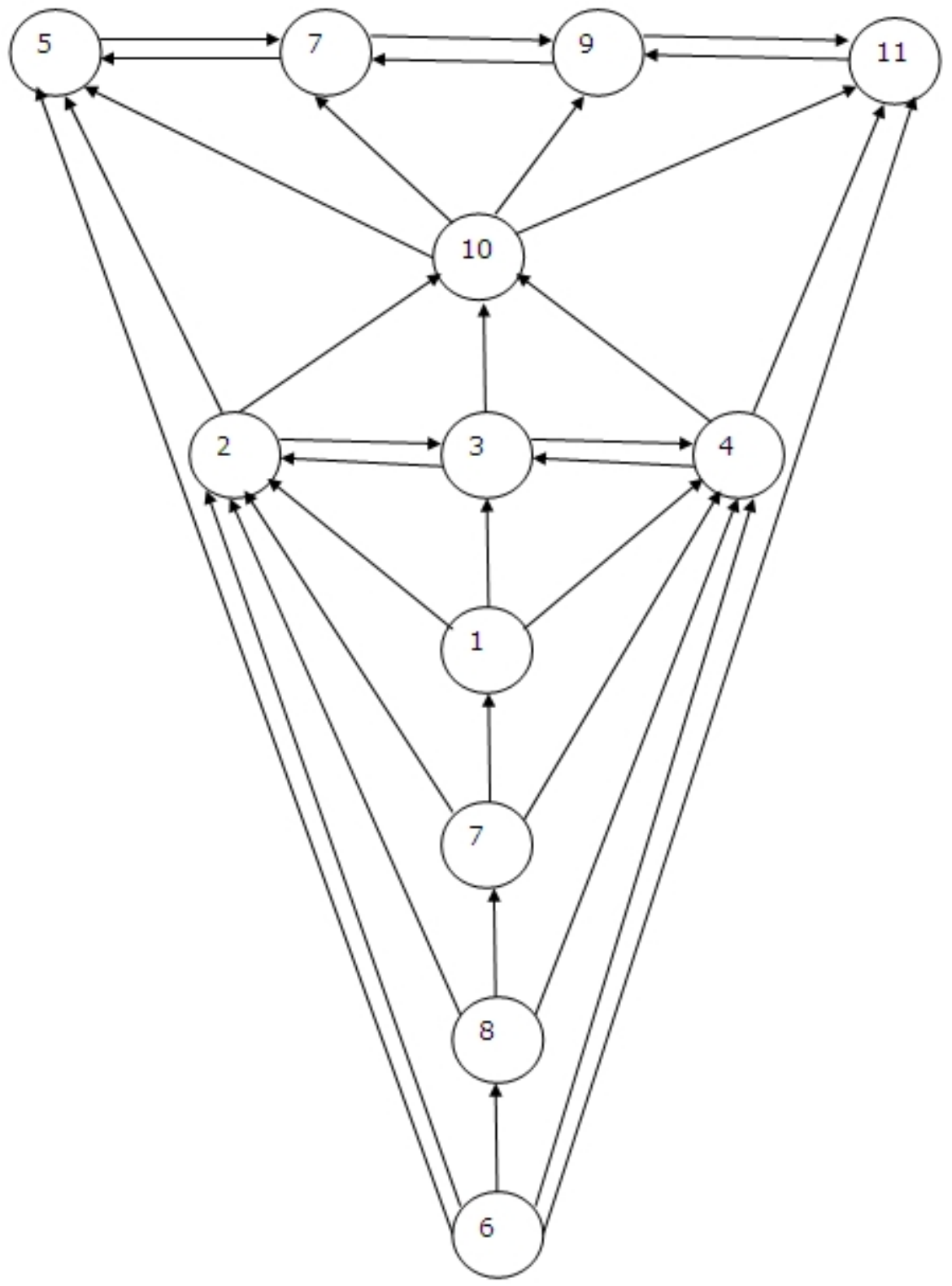

Figure 2. "Digraph of Barriers to Implement GSCM in Indian Automobile Industry". 


\begin{tabular}{|c|c|l|}
\hline S. N. & Level No. & I mportance of factors important to implement GSCM \\
\hline 1 & 1 st & $\begin{array}{l}\text { Market Competition and Uncertainty } \\
\text { Lack of Implementing Green Practices } \\
\text { Cost I mplications } \\
\text { Unawareness of customers }\end{array}$ \\
\hline 2 & 2 nd & Supplier Reluctance to change towards GSCM \\
\hline 3 & 3 rd & $\begin{array}{l}\text { Resistant to Technology Advancement Adoption } \\
\text { Lack of Organization Encouragement } \\
\text { Poor Quality of Human Resources }\end{array}$ \\
\hline 4 & 4th & Lack of IT Implementation \\
\hline 5 & 5th & Lack of Top Management Commitment \\
\hline 6 & 6 th & Lack of Government Support Policies \\
\hline
\end{tabular}

Table 7. "Various Levels of Barriers to Implement GSCM in Indian Automobile Industry".

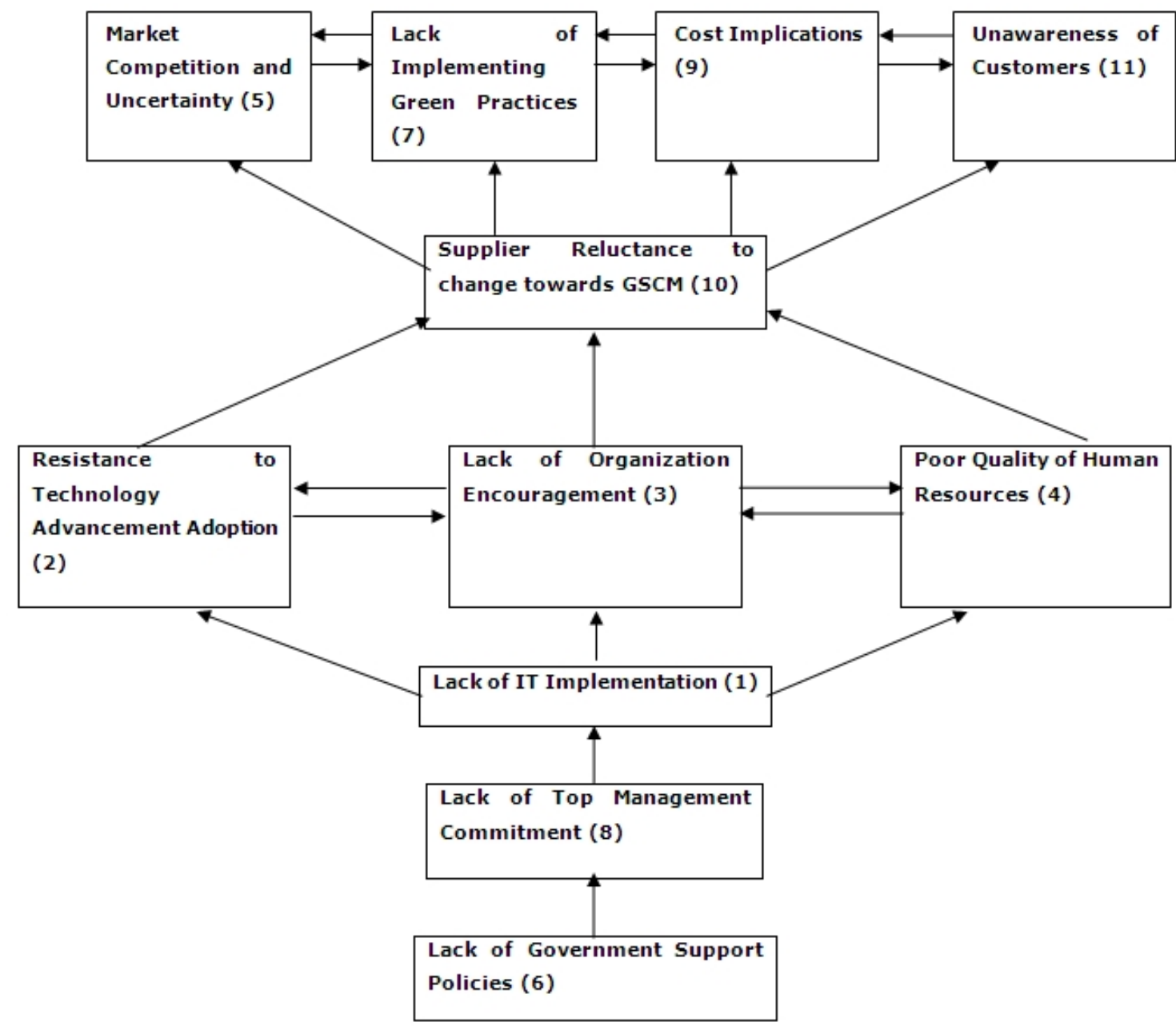

Figure 3. "ISM BASED Model for Barriers to Implement GSCM in Indian Automobile Industry". 


\section{Eliminating completely or making barriers less intense: proposed solutions}

Green practices should be promoted at international platforms like SAARC, WTO, WHO, CWO etc. effectively. International environment agreements may support Indian government to take initiatives towards green practices. ISO14001:2004 (Environment management system) and ISO26000:2010(Guidance on social responsibility) should be promoted by Indian government. In last few decades, many important steps have been taken to promote green practices. In 11th five year plan (2007-2012) environment and social responsibility is given special importance. There are several ministries (under Government of India) having direct and indirect role in controlling 'Green' issues like ministry of environment and forests; ministry of water resources; ministry of earth sciences and ministry of science and technology; ministry of mines and ministry of chemicals and fertilizers etc. these ministries should implement and control green policies and fund allocation more effectively. Indian government may announce some extra benefits to the organizations following green practices. Implementation of government policies towards green practices will lead to more committed top management. IT enablement will reduce a lot of paper work which will further reduce the need of cutting trees. Top management support is required to bear cost implications in IT enablement. IT enablement will also help in fast and effective communication among members of supply chain to achieve competent SCM. Well aware and good quality of human resources should be hired. I nitially, top management may find it more costly, ultimately it is going to help in implementing effective green practices. Regular training programs may be conducted to create awareness about green practices which will further help in organizations adoption and encouragement. Similarly top management commitment is required to encourage implement current technological advancements relevant to green practices. Government should take initiatives to make the customers aware about green products and how they are helpful to them. Special ad- campaigns and welfare programs by government departments like welfare ministry should be made to increase awareness level of customers. Organizations should make advertisements towards environment friendly products to create awareness among customers. Aware customers about green products would like to purchase green products, which will increase organization's reputation and sales volumes. Organizations implementing green practices can compete and export their products in world market. 
Organizations using improved environmental performance may lower their costs by reducing waste, also reducing their environmental compliance costs and lessening the threats of civil and criminal liability by preventing pollution. Innovative green practices may be motivated with Government support systems, Top management commitment, Technology advancement adoption, Organization encouragement, Quality of human resources and IT enablement. Innovative green practices involve hazardous solid waste disposal, energy conservation, reusing and recycling materials. Innovative green practices promote innovative design, new market opportunities and make their quality better than others. Innovative green practices includes Environment Management System(EMS) Implementation; Innovative Green Product Development Practices Adoption; Design for Environment; End of Life Product Management; Use of New Products and Process Optimization; TQM Practices Implementation; Green Procurement Strategies; Use of Environmental Friendly Transportation; Use of Environmental Friendly Packing and Labeling of the Products; Waste Management and Use of Recyclability Evaluation Methods(REMs); Proper Workplace Management; Use of Lean/Flexible Manufacturing which may help and support GSCM. Environment Management System (EMS) is managing environmental performance of the organizations. Green product development is the consideration of environment-friendly processes and materials at developmental stage. Design for environment is the consideration of recyclable and non harmful materials in design phase. End of life product management is safe disposal of products after successful end of the life. In today's scenario, product end life management is a major issue. Use and development of new environment-friendly products and process will help in improving environmental performance. Total Quality Management (TQM) is maintaining the quality of products and process from initial stage to final stage of the production. Green procurement strategies will help in purchasing environment-friendly materials and tools for the production. Use of environment-friendly transportation will help in reducing pollutions. Use of environmental friendly packing means use of recyclable or dissolvable materials for packing .Waste management and Recyclability Evaluation Methods (REMs) will help in managing and minimizing waste. Various recyclability methods will help in reduction of waste and improving the environment. Proper workplace management can help in stopping leakages and managing other resources in efficient and effective way. Use of lean or flexible manufacturing will help in continuous improvement and elimination of waste in all forms. 


\section{Conclusions}

Green supply Chain Management (GSCM) has been identified as an approach for improving performance of the processes and products according to the requirements of environmental regulations. Eleven barriers to implement GSCM in Indian automobile industry have been identified. Interpretive Structural Modeling (ISM) methodology has been used for finding contextual relationships among various barriers to implement GSCM in Indian automobile industry. A Model has been developed from ISM methodology. Market Competition and Uncertainty; Lack of Implementing Green Practices; Cost Implications; Unawareness of Customers and Supplier Reluctance to Change Towards GSCM have been identified as dependent variables. Lack of Government Support Systems; Lack of Top Management Commitment and Lack of IT Implementation have been identified as the driver variables. Resistance to Technology Advancement Adoption; Lack of Organization Encouragement and Poor Quality of Human Resources have been identified as the linkage variables. No barrier has been identified as autonomous variable. Market Competition and Uncertainty; Lack of Implementing Green Practices; Cost Implications; Unawareness of Customers have been identified as top level barriers and Lack of Government Support Systems as most important bottom level barrier. Removal of these barriers will be help in implementing GSCM in Indian automobile industry.

\section{Limitations of the study}

We have developed a hypothetical model of barriers to implement GSCM in Indian automobile industry based upon experts' opinions. The model may be tested in real world setting to check that the barriers are complete and their relationship exists as in the literature. The results of model may vary in real world setting. The barriers may be incomplete or their relationships may be different from the derived model.

\section{Scope of the future work}

We have considered eleven barriers to implement GSCM in Indian automobile industry. In case, a model needs to develop for another/allied industry or country, some barriers may be deleted while suitable ones are included. Structural Equation 
Modeling (SEM) may be used to test the validity of this hypothetical model. We have developed ISM model for the implementation of GSCM in Indian automobile industry. The ISM model for the implementation of GSCM in some other types of industry like electronics and electrical industry may be developed. Industry wise comparison may be made by using some different methodologies like Analytical Hierarchy Process (AHP) and Analytical Network Process (ANP).

\section{References}

AlKhidir, T., \& Zailani, S. (2009). Going Green in supply chain towards Environmental Sustainability. Global Journal of Environmental Research, 3(3), 246-251.

Beamon, B.M. (1999). Designing the Green Supply Chain. Logistics Information Management, 12(4), 332-342.

Borade, A.B., \& Bansod, S.V. (2007). Domain of Supply Chain Management -A state of Art. Journal of Technology Management and Innovation, 2(4), 109-121. ISSN: 0718-2724 (http://www.jotmi.org).

Chien, M.K., \& Shih, L.H. (2007). An empirical study of the Implementation of Green Supply Chain Management Practices in the Electrical and Electronics industries and their relation to organizational behavior. International Journal of Science and Technology, 4(3), 383-394. ISSN: 1735-1472.

Chien, M.K., \& Shih, L.H. (2007). Relationship between Management Practice and Organization Performance under European union directives such as ROHS, a case study on the Electrical and Electronics industry in Taiwan. African journal of Environmental Science and Technology, 1(3), 37-48. ISSN: 1996-0786.

Cooper, J. (1994). Green logistics, European logistics: markets, management and strategy. Oxford: Blackwell Business.

Digalwar, A.K., \& Metri, B.A. (2004). Performance Measurement Framework for World Class Manufacturing. International Journal of Applied Management and Technology, 3(2), 83-101. ISSN: 1554-4740(www.ijamt.org). 
Gant, R. M. (1996). Prospering in dynamically-competitive environments: Organizational capability as knowledge integration. Organizational Science, 7(4), 375-387.

\section{doi: $10.1287 /$ orsc. 7.4 .375}

Gilbert, S. (2000). Greening supply chain: Enhancing competitiveness through green productivity. Report of the Top Forum on Enhancing Competitiveness through Green Productivity held in the Republic of China, 25-27 May, 2000. ISBN: 92-833-2290-8.

Hamel, G., \& Prahalad, C.K (1989). Strategic Intent. Harvard Business Review, 67, 63-76.

Ho, Johnny C., Shalishali, Maurice K., Tseng T. Liang, \& Ang David, S. (2009). Opportunities in Green Supply Chain Management. The Coastal Business Journal, 8(1), 18-31. Electronic copy available at: www.coastal.edu/business/cbj/pdfs/art

Hosseini, A. (2007). Identification of Green Management of system's factors: - A Conceptualized Model. International Journal of Management Science and Engineering Management, 2(3), 221-228. ISSN 1746-7233, England, UK.

Hsu, C.W., \& Hu, A.H. (2008). Green Supply Chain Management in the Electronic Industry. International J ournal of Science and Technology, 5(2), 205-216. ISSN: 1735-1472.

Jharkharia S., \& Shankar, R. (2005). IT enablement of supply chains: understanding the barriers. J ournal of Enterprise Information Management, 18(1), 11-27.

http://dx.doi.org/10.1108/17410390610658432

Kannan, G., Noorul Haq, A., Sasikumar, P., \& Arrununchchalam, S. (2008). Analysis and Selection of green suppliers using interpretive structural modeling and analytic hierarchy process. International Journal of Management and Decision Making, 9(2), 163-182.

doi: 10.1504/IJ MDM.2008.017198 
Lamming, R., \& Hamapson, J. (1996). The environmental as a Supply Chain Management issue. British Journal of Management, 7(March Special Issue), 4562.

Lettice, F., Wyatt, C., \& Evan, S. (2010). Buyer-supplier partnerships during product design and development in the global automotive sector: who invests in what and when? International journal of Production Economics, 127(2), 309-319. doi: 10.1016/j.ijpe.2009.08.007

Luthra, S., Manju, Kumar S., \& Haleem A. (2010). Suggested Implementation of the Green Supply Chain Management in Automobile Industry of India: A Review. Proceedings of National Conference on 'Advancements and Futuristic Trends of Mechanical and Industrial Engineering, GITM, Bilaspur (INDIA), 12-13 Nov., 2010.

Mandal, A., \& Deshmukh, S.G. (1994). Vendor selection using interpretive structural modeling(ISM). International Journal of Operations and Production Management, 14(6), 52-59.

\section{doi: $10.1108 / 01443579410062086$}

Mclaren, Tim S., Head, Milena M., \& Yuan, Yufei (2004). Supply Chain Management Information System Capabilities: An Exploratory Study of Electronics Manufactures. Information systems and E-business management, 2(3), 207-222. doi: 10.1007/s10257-004-0035-5

Mudgal, R.K., Shankar, R., Talib, P., \& Raj, T. (2009). Greening the supply chain practices: an Indian perspective of enablers' relationship. Int. Journal of Advanced Operations Management, 1(2 and 3), 151-176.

doi: 10.1504/1]AOM.2009.030671

Mudgal, R.K., Shankar, R., Talib, P., \& Raj, T. (2010). Modeling the barriers of green supply chain practices: an Indian perspective. Int. Journal of Logistics Systems and Management, 7, 1, 81-107. Electronic copy available at: http: // inderscience. metapress. com/link. asp? $i d=8343$ t48231372825

Olugu, E.U., Wong, K.Y., \& Shaharoun, A.M. (2010). A Comprehensive Approach in Assessing the Performance of an Automobile closed loop Supply Chain. Sustainability, 2, 871-879.

doi: $10.3390 /$ su2040871 
Ravi, V., \& Shankar R. (2005). Analysis of interactions among the barriers of reverse logistics. International Journal of Technological Forecasting \& Social change, 72(8), 1011-1029.

Rogers, D.S., \& R.S. (1998). Tibben- lembke, Going Backwards: Reverse Logistics Trends and Practices. Reverse Logistics Executive Council, Pittsburgh, PA.

Sage, A. (1977). Interpretive Structural Modeling: Methodology for Large scale Systems (pp. 91-164). New York: McGraw-Hill.

Sarkar, A., \& Mohapatra, P.K. (2006). Evaluation of supplier capability and performance: A method for supply base reduction. Journal of Purchase supply Management, 12, 148-163.

Sarkis, J. (2009). A Boundaries and Flows Perspective of Green Supply Chain Management. GPMI working papers. No-7, October 2009.

Scupola, A. (2003). The adoption of internet commerce by SMEs in the South of Italy: an environmental, technological and organizational perspective. Journal of Global Information Technology Management, 6(1), 52-71.

Srivastva, S. (2007). Green supply State of the art Literature Review. International Journal of Management Review, 9(1), 53-80.

doi: 10.1111/j.1468-2370.2007.00202.x

Torres, B., Nones, S., Morques, S., \& Evgenio, R. (2004). A Theoretical Approach for Green Supply Chain Management. Federal University DO RIO GRANDE, Industrial Engineering Program, NATAL-BRAZIL, J anaury-2004.

Tsai, W., \& Ghoshal, S. (1998). Social capital and value creation: the role of intra firm networks. Academy of Management Journal, 41(4), 464-476. Electronic copy available at: http://www.jstor.org/stable/257085.

Warfield, J.W. (1974). Developing interconnected matrices in Structural modeling. IEEE Transcript on Systems, Men and Cybernetics, 4(1), 51-81.

Wu, G. C., \& Hang, S. Y. (2009). The study of knowledge transfer and green management performance in green supply chain management. African journal of 
Business Management, 4(1), 44-48, Accepted 03 November 2009. ISSN: 19938233.

Yu Lin, C. (2007). Adoption of green supply in Taiwan logistic industry. Journal of management study, 90-98. Electronic copy available at: www.jimsjournal.org/10\%2520Chieh-Yu\% 2

Yu Lin, C., \& Hui Ho, Y. (2008). An Empirical Study on Logistics services provider, intention to adopt Green Innovations. Journal of Technology, Management and Innovation, 3(1), 17-26. Electronic copy available at: www. redalyc. uaemex.mx/pdf/847/84730103.pdf

Zhu, Q., \& Sarkis, J. (2004). Relationship between Operational practices and Performance among Early Adopters of Green Supply Chain Management Practices in Chinese Manufacturing Enterprises. Operations Management, 22, 265-289. Electronic copy available at: http://www.sciencedirect.com/science/journal/02726963

Zhu, Q., \& Sarkis, J. (2007). The moderating effects of institutional pressures on emergent green supply chain practices and performance. Electronic copy available at: http://ssrn. com/abstract $=973416$.

Zhu, Q., Sarkis, J. \& Lai, K. (2007). Green Supply Management: Pressures, Practices and Performance within the Chinese Automobile Industry. Journal of Cleaner Production, 15(11-12), 1041-1052. Electronic copy available at: www.sciencedirect.com

Zhu, Q., Sarkis, J. \& Lai, K. (2008). Green supply chain management implications for "closing the loop". Transport Research Part E, 44(1), 1-18.

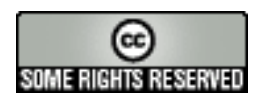

Article's contents are provided on a Attribution-Non Commercial 3.0 Creative commons license. Readers are allowed to copy, distribute and communicate article's contents, provided the author's and Journal of Industrial Engineering and Management's names are included. It must not be used for commercial purposes. To see the complete license contents, please visit http://creativecommons.org/licenses/by-nc/3.0/. 